\section{THE PROGRESS OF NATURAL SCIENCE DURING THE LAST TWENTY-FIVE YEARS II.}

Duri URING the last quarter of a century, the history of the formation of our earth has assumed a new aspect. When the Cosmos appeared, the opinion prevailed that our earth, once a globe of liquid fire, became covered with a crust of congealed scorix, on which, byand-by, the first animal and plant life made its appearance; after an almost infinite length of time, during which the Silurian, Devonian, Carboniferous, and Permian strata were deposited, a terrible catastrophe, affecting simultaneously the whole earth, so completely destroyed the first palæozoic life, that not a single species survived the universal devastation. Upon the lifeless expanse, it was supposed, appeared then, forming the Secondary Fauna and Flora, entirely unconnected with and different from the extinguished one, until after frequent repetitions of the same process at longer or shorter intervals, man made his appearance, and along with him all existing plants and animals: with him begins the Historical Period, whose duration has not exceeded 6,000 years. The causes of these world-wide revolutions Geology sought in the violent reaction of the molten interior against the once extremely slender crust.

In opposition to these views, the opinion peculiarly associated with the name of Lyell has made way, that no violent revolutions, returning at intervals, destroyed the external structure of the earth and all the life it sustained, but that all changes even in the earliest times affected only the earth's surface, and that these could only be the results of the same powers of nature which are actively at work on the earth at the present time; and that moreover, the gradual, but ever active powers of water, of air, and of chemical change, have perhaps had a greater share in accomplishing these transformations, than the ficrce 1 eat of subterranean masses of lava. The explorers of the buried remains of plants and animals show it to be impossible that all life in those geological formations could have been destroyed simultaneously, for many species are common at several stages; in particular many existing animals and plants reach far back into the primitive world. Man himself could be shown to have been contemporary with many extinct species of plants and animals, and therefore his age on the earth must be extended back to an indefinite period. Man was witness to that inundation which buried the plains of the old and the new world under the waves of the sea of ice. Even in the immediately preceding period, when the subtropical elephant, rhinoceros, and hippopotamus disported themselves in the lignite woods of Middle Europe, have traces of mankind been found. Only in the most recent times has a foundation been laid for the pre-historic records of mankind, by means of which we may be able to obtain a knowledge of the state of civilisation, weapons, implements, and dwellings of that primitive race.

No book of recent times, Dr. Cohn thinks, has influenced to such an extent the aspects of modern natural science, as Charles Darwin's work "On the Origin of Species," the first edition of which appeared in 1859 . For even to so late a period, was the immutability of species believed in ; so long was it accepted as indubitable that all the characteristics which belong to any species of plants andanimals were transmitted unaltered through all generations, and were under no circumstances changeable; so long did the appearance of new fauna and flora remain one of the impenetrable mysteries of science. He who would not believe that new species of animals and plants, from the yeastfungus to the mammalia, had been crystallised parentless out of transformed materials was shut up to the belief that in primeval time an omnipotent act of creation, or, as it may be otherwise expressed, a po:ver of nature at present utterly unknown, interfered with the regular progress of the world's development; yea, according to the researches of D'Orbigny and Elie de Beaumont, twenty-seven different acts of creation mu:t have followed each other previous to the appearance of man-but after that, no more. It was Darwin who lifted natural science out of this dilemma, by advancing the doctrine that the animals and plants of the late geological eras no more appeared all at once upon the scene, than those of the preceding epochs simultaneously and suddenly disappeared; on the contrary, these are the direct descendants of former species, which gradually in the course of an exceedingly long period, through adaptation to altered conditions of life, through the struggle for existence, through natural and sexual selection have been changed into the new species. Professor Cohn does not doubt but that Darwin and his school may have over-estimated the reach of the explanations given by him to account for the transmutation of species, and especially the importance of natural and sexual selection, but the fundamenta? frot has been established, and will remain so for all futric time. This fact is that the collective life of the earth, fiom the beginning ever until now, and from the fungus-cell up to mar, represert a single series which has never once been broken, whose members through direct propagation have proceeded out of each other, and in the coursc of a vast period have been developed into manifold and, on the whole, perfect forms.

The sciences which are concerned with life have during late years been cultivated on all sides; even in earlier years Cuvier and Jussieu had done as much for zcology and botany as the state of discovery in their time permitted, but since 1858 the boundaries of both kingdoms have been widely extended by the labours of Carpenter, Huxley, and Pourtalès.

After referring to the researches of Goethe in the last century, and those of Bauer and of Johannes Müller in the present, in reference to the physiology of plants and animals, Prof. Cohn says it was only in our own time, and first in I 843 in Scbleiden's "Grundzügen der Wissenschaftlichen Botanik," that the new principle was followed out ; the principle, namely, that all vegetable phenomena and all the various forms of plants proceed from the life and the development of their cclls. After Schwann discovered that animal bodies also were built up from an analogous cell, mainly by Virchow was then developed from this principle the modern cellular physiology and pathology which traces the cordition both of healthy and diseased men and animals back to the life-function of their cells. But; as the lecturer says, to attempt to follow out the advances made by science in these directions during the last twenty-five years would require a large volume, and cannot be done in the space of a lecture or an article. 
Even the cell itself has been changed. Until Schleiden's time it was a little bleb filled with fluid; we now regard it as a soft glutinous body constructed out of the albuminous protoplasm first distinguished by $\mathrm{Mohl}$ in 1845 , and which is covered with a cellular integument, as the oyster is with its cell. After waxing eloquent over the cell as an entity, an "ego" by itself, and its relations to the outer world, Prof. Cohn says that science now teaches us that there is only one life and one cell, the cell of plants and of animals being essentially the same. The most highlydeveloped animal differs from the simplest plant only in the number and greater development of the matter composing the cells, but above all, to the more complete elaboration (Arbeitstheilung), and the stricter subordination of the separate cells to the collective life of the organism. Between the two extremes of the living world, the yeast-fungus and man, there is the same difference as there is between a group of individual men who do $\mathrm{n}$ t know how to organise their strength, and a strictly -disciplined, well-ordered army suitably formed and well armed, and which, by the strict subordination of the many wills to the central authority, is always equal to the highest achievements.

It is true that these scientific researches into biology have left as yet the most important questions unsolved. It is not yet possible to $\mathrm{r}$ ggard all life-processes as simple modifications of the other forces of nature and to ascertain thair mechanical equivslents; we cannot yet convert absolute heat or light into life; and although chemistry is daily doing more and more to bridge over the gaping chasm which once separated the organic and inorganic systems, it has not yet succeeded in finding out the precise matter which exclusively supports the life-process, on which alone the cells subsist. Thus, then, the beginning of life is still wrapped in obscurity.

After referring in this connection to the transmission of epidemic $z$ amongst plants, animals, and man, and to the microscopical labours of Leeuwenhoek, Ehrenberg, Gagniard-Latour, Schwann, and Kützing, Prof. Cohn goes on to say that the investigators of the present time, to whom Pasteur has given a powerful impulse, have been the first to establish beyond doubt that without Bacteria no putrefaction, and without yeast-fungi no fermentation takes place ; that this decomposition is accomplished only through the sustenance and living activity of those microscopic cells.

Many a mystery of life will doubtless be unfolded to us if our op:icians during the next twenty-five years should manage to raise the power of the microscope in the same proportion as in the previous quarter of a century, in which it has been at least quadrupled. The best microscope of Schiek and Plössl in 1846 did not magnify more than 500 diameters; the "immersion-lens xv." of Hartnack over 2,000 diameters. Still Dr. Cohn does not venture to hope that during the next twenty-five years all the questions of science which are at present being agitated will be solved. As one veil after another is lifted, we find ourselves behind a still thicker one, which conceals from our longing eyes the mysterious goddess of whom we are in search.

Dr. Cohn, in concluding his eloquent address, attempis to point out the characteristics which distinguish the present from the past generation. In the former epoch students confined their researches to single and carefully marked off divisions of nature, without any regard to the neighbouring and closely allied regions, which must necessarily lead to the one-sided view that these divisions belong to Nature herself. In the present generation, on the other hand, the several physical sciences have entered into the closest organic union. Physics and chemistry along with mathematical astronomy and geology, have been blended into a new science-the history of the development of worlds; palæontology, systematic botany, and zoology have been joined into a united science of organisms; the physiology of plants and of animals have become coalesced in universal biology; the boundary between the organic and inorganic aspects of nature is being ever more and more obliterated, and out of the several natural sciences a single uniform, universal natural science is being constructed.

But the deeper natural science penetrates from outward phenomena to universal laws, the more she lays aside her former fear to test the latest fundamental questions of being and becoming (Sein und Werden), of space and time of matter and force, of life and spirit, by the scale of the inductive method, and the more confidently she lifts her views concerning the universe out of the cloudy atmosphere of hypothesis into the clear ether of theory grounded on fact, so much the more will the gap be narrowed which since Kant has separated science from philosophy. Schiller's advice to philosophers and men of science-

"Feindscha't sei zwischen euch; noch ist das Bundniss zu fruhe ;

Nur wenn in Kampf ihr euch treant, dann wird die Wahrheit enthult,"

has been followed for more than half a century, to the gain of the natural sciences, but often to the injury of philosophy, which would knock away the firm ground from under our feet. But since Herbart and Schopenhauer, and especially through Hartmann's labours, have the two chief drifts of the work of the human mind been approaching; and if natural scierce has a mission to mould the future of our race, she must court the purifying influence of philosophical criticism: and this mission, in Dr. Cohn's estimation, the science of the future cannot reject. Its importance rests not merely in the much interesting and useful information which can be made available to trade and industry, for daily economy and universal civilisation; she must build a sure foundation for our collective view of the universe, for our knowledge of ultimate and highest things. It must be no longer the case that even our most educated classes, in consequence of insufficient education, have neither interest nor intellizence for the pursuit and acquisition of scientific knowledge. Moreover, science will be no more able to shun battle with other systems of the universe which have been hallowed by the traditions of a thousand years, than were Socrates and Aristotle, Copernicus and Galileo. Victory will lie on the side of truth.

But if anxious souls should fear that with the advance of a scientific knowledge of the universe among the people, would come a breaking up of political and social order, let them be assured by the teaching of history. When we perceive the flash of an electric spark we certainly do not take it for a bolt darted by the revengeful Jupiter: and as the vault of Heaven is resolved into air and light, so also must the Olympus be shattered which was built thereon. But the ideas of the true, the beauti- 
ful, and the good remain unshaken; they have been all the more firmly established, for they have been deduced from the order of the universe and from the mind of man frimself. And that the pursuit of natural science does not lead to materialism, and in no way injures the ideal mind, is vouched for by the case of Alexander von Humboldt him self, who, even in extreme old age, kept up his love for research and power of work as well as his lively susceptibility for and energetic share in all the noble pursuits of mankind.

Dr. Cohn concludes his lecture, so brimful of true eloquence founded on sober fact, with a high compliment to the many worthy qualities of the President of the Silesian Society, Dr. Goeppert. Such a man as he is said to be, the lecturer truly says, may hope, like Goothe, Humboldt, and other previous philosophers, to maintain to the utmost limit of existence, life, heart, and spirit full of the freshness of youth, and, moreover, in later generations be honoured as a true guardian of the highest good of grateful mankind.

\section{VALENTIN'S CHEMISTRY}

Introduction to Inorganic Chemistry. By W. G. Valentin, F.C.S. (London: J. and A. Churchill.)

W ${ }^{E}$ must congratulate the author on the appearance of this volume. It is in reality a second and much improved edition of the first part of "Valentin's Introduction to Qualitative Analysis," and it is very encouraging that a second edition is so soon wanted. This book is one of a class which for the sake of English science we could wish were more numerous. It teaches chemistry entirely by practical work, and at the same time gives the student a clear knowledge of the general principles of the science. The very first words, indeed, afford a good idea of the system pursued throughout the work. Experiment I.- "Fill a glass cylinder or a test-tube with water, and invert it over a basin containing water, \&c." This experiment is the collection of hydrogen evolved from the action of sodium on water. This quotation may be taken as almost typical of the book. The methods of preparation and the properties of the various elements and simple compounds are studied by means of very carefully described and well-chosen experiments, and from his experiments the student is taught to draw deductions and generalisations. In this way the fundamental laws of chemistry are deduced from experimental facts, and a sound foundation of chemical knowledge is obtained. This method scarcely rcquires any recommendation; the fact that the author has adopted it after a long experience of practical teaching in one of our largest laboratories is one proof amongst many that the practical system of teaching is the only one which yields good and satisfactory results. This method of experimental teaching is now coming more and more into general use, and perhaps to a greater extent in chemistry than in any other science.

In the work before us there are 169 experiments carefully described, most of which are suitable for the student himself to perform; there are a few, however, the successful performance of which is almost beyond the capabilities of young beginners. The selection of experiments is left to individual teachers, and must depend to some extent also on the resources of the laboratory. It is a question 'whether some few of them are not more suitable for the lecture tabile, or to be performed under the immediate superintendence of the teacher. It would, perhaps, have been an improvement if the author had distinguished those experiments which he thinks are necessary for the student to perform. This would certainly assist a student working privately, and would to some extent be a sort of moral obligation on some teachers who might be inclined to run through the book superficially. Most of the experiments may b: successfully performed if the directions in the book are adhered to, which are for the most part fully and clearly expressed. At the end of each chapter there is a short résume, printed in italics, of the principal facts which have been demonstrated, and these form a very valuable part of the book. At the end of many chapters there is also placed a number of questions and exercises on the substance matter of the book, dealing, however, more particularly with those points which are found to be stumbling-blocks to students. It is recommended that the answers to these should be written out and examined by the teacher, which, though it would involve a considerable amount of labour, would render the laboratory teaching much more thorough and efficient. Many of the questions are by no means easy, and a student who can conscientiously answer them will have acquired a very fair knowledge of elementary inorganic chemistry.

The notation used is the same as that employed by Dr. Frankland in his "Lecture Notes." This, perhaps, may be a drawback to the use of the book by some teachers, although it appears that of late years this system has gained much ground. It consists essentially in the use of a series of compound radicals formed on the type of hydroxyl or peroxide of hydrogen, and in the employment of thicker type to represent certain elements which act as the grouping elements of each compound. Thus sulphuric acid is represented as consisting of the radical $\mathbf{S O}_{2}$ combined with two semimolecules of hydroxyl, thus $\mathbf{S O}_{2}(\mathrm{HO})_{2}$, or, written according to the abbreviated formula, $\mathrm{SO}_{2} \mathrm{Ho}_{2}$, when Ho represents a semi-molecule of hydroxyl ; a sulphate, as, for instance, sodic sulphate, would be represented as $\mathbf{S O}_{2}(\mathrm{NaO})_{2}$, or $\mathbf{S O}_{2} \mathrm{NaO}_{z}$, in which the monad radical $\mathrm{Nao}$ (sodoxyl) has replaced hydroxyl, basic sulphate would be $\mathbf{5} \mathrm{S}_{2}\left(\mathrm{BaO}_{2}\right)$, , or $\mathbf{5} \mathrm{S}_{2} \mathrm{Bao}^{\prime \prime}$, in which $\mathrm{BaO}^{\prime \prime}$ is a compound dyad radical, consisting of one atom of barium and two of oxygen, and replaces the two semi-molecules of hydroxyl. The author uses the second of these formulæ throughout the work, although, perhaps it would appear slightly less complicated if the first of these two kinds of formulæ had been used. This system of formulating bodies with the use of this class of radicals has been employed for many years in the field of organic chemistry, so much so, that it is impossible to study this branch without being familiar with the system. We cannot see any reason why inorganic chemistry should not be treated in a similar manner, and we believe that this system will gradually and surely spread. Graphic illustration is also employed, and is very useful in explaining the constitutional symbolic formulæ employed in the book. There seems no doubt that the fear that students would materialise, as it might be called, thesegraphic representations 